\title{
Gender Differences in Learning Style Preferences among Eleventh Grade Science Major High School Students
}

\author{
Hafizhah Dini Nasution ${ }^{1}$, Herbert Sipahutar ${ }^{2 *}$, Tumiur Gultom ${ }^{2}$ \\ ${ }^{1}$ Post graduate Biology Education of UniversitasNegeri Medan, Jalan Willem Iskandar Psr V Medan Estate, \\ North Sumatra 20221, Indonesia \\ ${ }^{2}$ Department of Biology, Faculty of Mathematics and Natural Sciences UniversitasNegeri Medan, Jalan Willem \\ Iskandar Psr V Medan Estate, North Sumatra 20221, Indonesia
}

*Corresponding Author: Herbert Sipahutar, Department of Biology, Faculty of Mathematics and Natural Sciences UniversitasNegeri Medan, Jalan Willem Iskandar Psr V Medan Estate, North Sumatra 20221, Indonesia

\begin{abstract}
This study was conducted to find out learning style preferences among eleventh grade science major high school students. We used the VARK instrument to science major eleventh grader high school students in Al-Azhar Medan High school, Medan, Indonesia. By Solvin's method, 114 out of 159 students became sample for this study and voluntarily offered gender information. The results of students learning styles in order were: multi modal (50.9\%), Audio (12.3\%), Kinesthetic (8.8\%), Audio-Kinesthetic (5.3\%), Visual-Audio-Kinesthetic (5.3\%), Audio-Read/Write-Kinesthetic (5.3\%), visual (3.5\%), Visual-Kinesthetic (5.3\%), Read/Write (1.8\%), Visual-Audio-Read/Write (1.8\%), Audio-Read/Write (0.9\%), and VisualRead/write-Kinesthetic (0.9\%). Further, none of them have Visual-Auditory, Visual-Read/Write, and Read/Write-Kinesthetic Learning Styles. Students Learning Styles if grouped according to gender shows higher frequency of male students in Visual, Auditory, Kinesthetic, VAK and VARK types. Frequency of female students was higher compared to male in Reading, AR, AK, VAR, VRK and ARK types. Overall result indicated male and female students have no significant difference in learning styles ( $p>0,05)$.
\end{abstract}

Keywords: Learning styles, VARK, high school, gender, science

\section{INTRODUCTION}

Learning style falls into the categories of dispositional qualities and characteristic versions where there are dissimilarities across individuals but there are groupings of individuals who have similar learning style characteristics. Coffield, Moseley, Hall, and Ecclestone have been identified at least 71 learning styles models have been found [1]. Among them, there are six well-known and widely available instruments commonly used by researchers such as learning styles by Kolb, Gregorc, Felder-Silverman, Fleming, and Dunn and Dunn as well as the Entwistle and Tait Revised Approaches to Studying model [2].

Flemming and Mills [3] described the dissimilarities in learning approaches for the four VARK Learning Styles. Students with a V preference learn best by seeing or observing (drawings, pictures, diagrams, demonstrations, etc.). Learners that prefer A are best suited to learn by listening to or recording lectures, discussing material, and talking through material with themselves or others. R-type learners learn through interactions with textual materials. K-style learners perform best by using physical experiences: touching, performing an activity, moving, lessons that emphasize doing, and manipulation of objects. Student learners are capable of using all of these sensory modes of learning; however, each individual has a unique preference, or set of preferences, in which one mode is often dominant [1]. Learners with a single learning style preference are referred to as unimodal, whereas others preferring a variety of styles are known as multimodal. Of the multimodal learners, there are sub classifications for bi-, tri-, and quadmodal learners, who prefer to use two, three, or four styles, respectively.

Flemming VARK's instrument has been widely used in many research across field. Valerdy et al. [4] has listed several benefits why VARK questionnaire chosen, such as: (1) VARK has been documented by researchers outside of the group that originated it, providing valuable information and lessons learned from applying it to measure learning preferences in different disciplines; (2) VARK 
instrument has been validated by other researchers, especially in Biology-related fields $[5,6,7,8]$; (3)VARK has gone through several literation of improvements (currently in version 7) which capture several years of experience and analysis; (4)VARK provides benchmarking opportunities between existing data and newly collected data. This is particularly helpful when comparing across gender, students/teachers, and fields of study.

There are differences in the VARK preferences of students across different disciplines. For example, law students and faculty usually have larger proportions of Read/Write. Nursing students are more likely to have kinesthetic preferences [6].Graphic designers, performing arts and computer systems students are stronger on the Visual dimension. Performing arts and applied science students have more single preference Visual profiles than other disciplines[4].

Several studies regarding student's learning styles also have been documented in science related field. Majority of university students in science-related field have been reported have multimodal styles $[9,10]$. However, researches in Indonesian high school, students tend to have Visual type [11,12].Further, Wehrweinet al. [9] found out majority of male students preferred multimodal instruction, specifically, four modes (VARK), whereas a majority of female students preferred singlemode instruction with a preference toward Kinesthetic type.

Understanding students learning styles preference are important because it will improve instructions. By gaining knowledge of a few properties (e.g., answers on a questionnaire), teachers hope to infer other characteristics (e.g., how the student will respond to different types of instruction) that can be used to improve the educational process [13].Further, according to Sternberg and Grigorenko[14], the study of styles have several benefits such as: providing a link between cognition and personality; understanding, predicting, and improving educational achievement; and improving vocational selection, guidance, and possibly, placement.

Among many factors that may sometimes affect learning style preferences is gender. A number of studies have shown a relationship between gender and learning style preferences of the students. Since the past few years, there has been a renewed interest in studies related to gender differences among students in higher schools in both in the world and Indonesia [15,16,17,18].However, this issue has been debated many times in the literatures is whether gender difference may affect an individual's preferences in learning [17,22]. Therefore, study about gender difference in learning styles also became our concern in this study. Understanding of the learning style preferences of students can provide effective learning strategies for teachers to use (Lohri-Posey, 2003).

Students who share a learning style that is attuned with the teacher remember information longer and are more optimistic about learning (Lohri-Posey, 2003).

\section{METHODS}

\subsection{Design and Procedure}

To find out student's learning style preferences, we used the VARK instrument developed by Fleming to eleventh grader students who take biology course in Al-Azhar Medan high school. The information about student's general information such as student's name and gender also include in the instrument. Out of 159 students, we took 114 students (48 male, 66 females) as sample of this study by using Slovin's method, random sampling.

\subsection{Analysis}

Student's learning styles preference was determine by method provide by Flemming's. Data are reported as percentages of students in each category of learning style preferences. The number of students who preferred each mode of learning was divided by the total number of responses to determine the percentage. Spearmann correlation analysis was firstly performed to measure the relationship between each dimension of Flemming VARK's learning style and gender. Independent sample t-test then performed to find out whether there was significant difference in learning styles between male and female students.

\section{RESULTS}

Data analysis on student's learning styles (Figure 1) shows student's learning styles in Al-Azhar Medan High school in order was: multi modal (50.9\%), Audio (12.3\%), Kinesthetic (8.8\%), AudioKinesthetic (5.3\%), Visual-Audio-Kinesthetic (5.3\%), Audio-Read/Write-Kinesthetic (5.3\%), visual 
(3.5\%), Visual-Kinesthetic (5.3\%), Read/Write (1.8\%), Visual-Audio-Read/Write (1.8\%), AudioRead/Write $(0.9 \%)$, and Visual-Read/write-Kinesthetic $(0.9 \%)$. Further, none of them has VisualAuditory, Visual-Read/Write, and Read/Write-Kinesthetic Learning Styles.

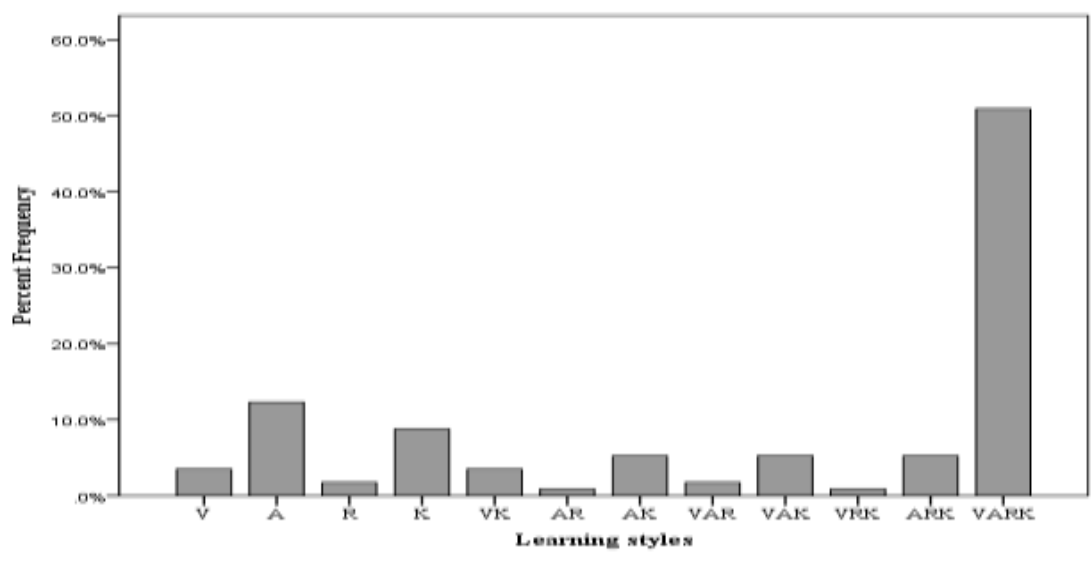

Figure1: Student's Learning Styles frequency percentage

Student's learning styles, if it is grouped based on its Modality (Figure 2), shows the most students have quad-modal type (50.88\%), the second highest have uni-modal type (26.32\%), followed by trimodal $(13.16 \%)$, and bi-modal type $(9.65 \%)$,

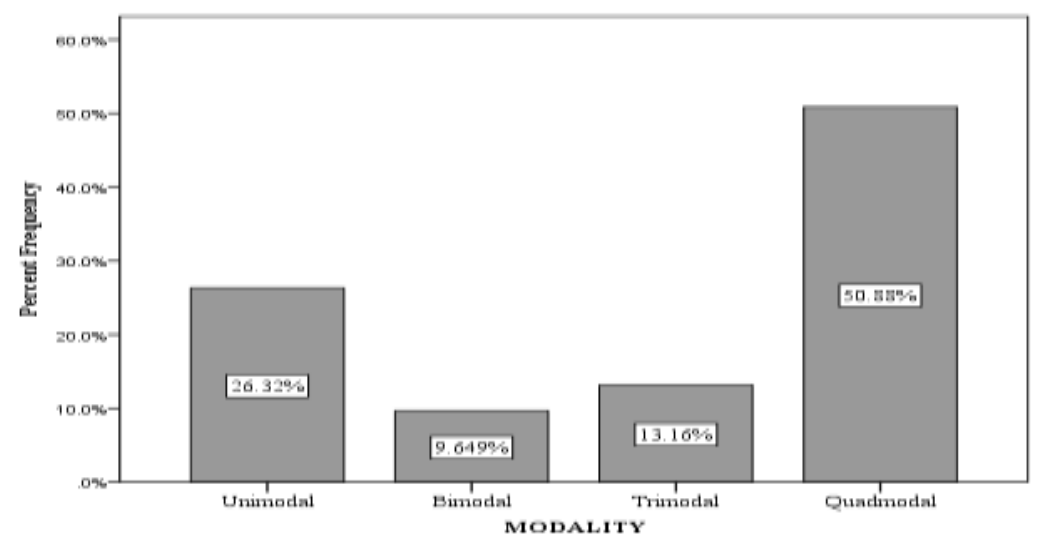

Figure2: Student's Learning Styles distribution according its modality type

Students Learning Styles if grouped according to gender (Figure 3), shows higher frequency of male students in Visual, Auditory, Kinesthetic, VAK and VARK types. Frequency of female students was higher compared to male in Reading, AR, AK, VAR, VRK and ARK types. According to its modality (Figure 4), frequency of female students was higher in Bimodal (4.39\% higher), Tri-modal (4.38\% higher) and Quad-modal (7.02\% higher).

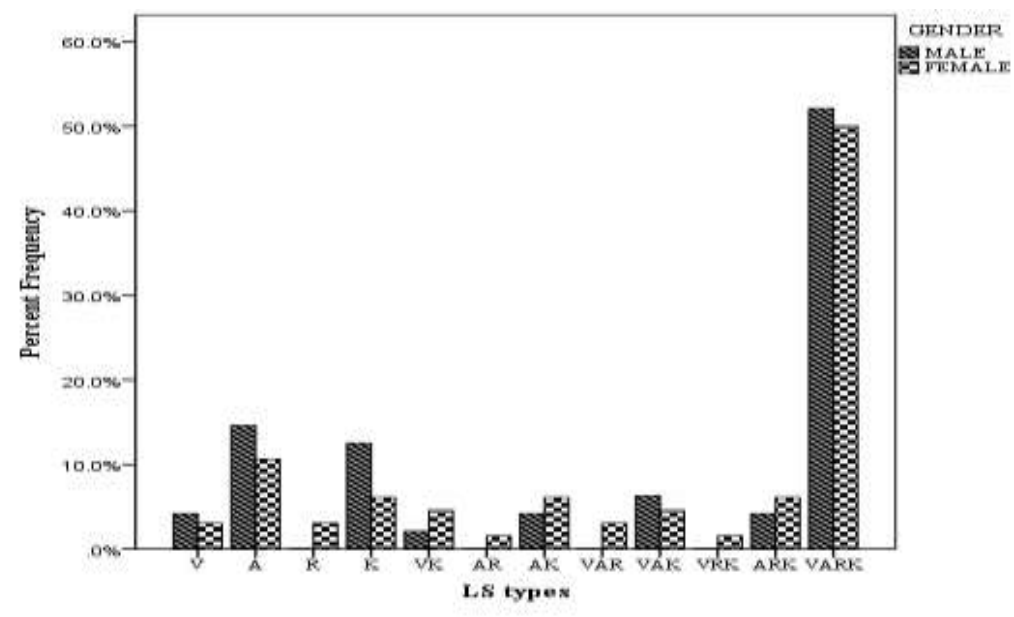

Figure3: Learning Styles of male and female students 


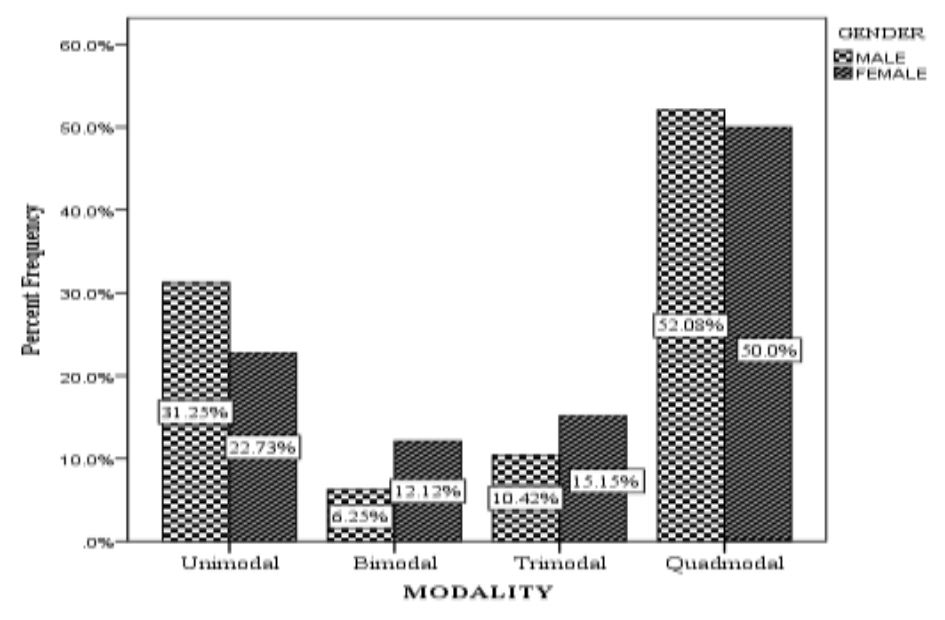

Figure4: Learning Styles of male and female students according to its modality

Spearmann correlation analysis was firstly performed to measure the relationship between each dimension of Flemming VARK's learning style and gender. The spearman correlation analyses confirmed that there are no statistically significant differences between male and female students with respect to all learning style preference $(\mathrm{p}>0,05)$. To provide further insights into the gender influence on respondents' preferred learning styles, an independent t-test analysis was performed to confirm the findings as obtained in the correlation. Analysis by using Mann Whitney U test obtained $\mathrm{p}$-value $=0.640\left(\mathrm{t}_{\text {count }}=-0.469\right)$. The $\mathrm{p}$-value was greater than significant level 0.05 , in the other words there was no significant difference in learning styles between male and female students.

\section{DISCUSSION}

Result of our study indicated that most students have quad-modal learning styles (VARK). The same result also obtained in science related field in undergraduate level, such in biology and physiology majors $[9,10]$. From single preference perspective, Reading and writing are the least preferred style both in male and female. We assumed this is due to the fact that school or teacher do not adequately improve students reading and writing abilities and skills and thus making these skills least preferred. Further, from single preference perspective, male students tend to be Kinesthetic learner. This was in line with study by Braakhuis et al. [19] which found out the majority of athletes, had a Kinesthetic learning style and especially Male athletes were found to prefer K learning (39\%).

Another purpose of the study was to assess gender differences in learning style preferences among high school students in learning biology. We found out that there was no statistically significant difference in learning styles between male and female students ( $\mathrm{p}$-value $=0.635$ ). Our result has similar result with recent study by Yemane et al [17] and Gunes[18] which are also found that there was no significant difference in learning style preferences between the two gender. As comparison, learning styles differences also not found in other major such as in linguistic students [20, 21, 22].

The findings in this study strengthen some scholar argument that it may not be necessary for teachers to implement a gender-sensitive approach in designing science materials. Paechter[23],suggested educational providers need to find ways to show that gender-marking is not necessary to enable both male and female students to involve in all aspects of the curriculum. The similarity in learning style preferences between male and female students in this study could be partly due to the changing learning environment with increasing technological influences where students are more and more adapting themselves to such changes, regardless of their gender difference. This is supported by Rosseni et al. [24], that found out there are no gender differences when it comes to ability in gaining meaningful learning experiences through technology. Another reason could also be because of the sample of population, course learning, environment condition or facilitator [25]. Learning condition such as didactic learning exposure makes gender has no influence on learning styles [22]. Student's long exposure to traditional approach in education where didactic method of teaching is dominating may suppress any gender differences in learning process [26]. According to Alkoheeji and Al-Hattami [27] what mostly affected the preferences, however, was the type of activities or tasks students perform while learning. Further they suggested that VARK preferences need to be related to activity type rather than be observed at individual reference. 


\section{CONCLUSION}

Diagnosing and understanding students' learning styles is no doubt, important from pedagogical aspect. It is clear that each student has a specific learning style, and as noticed, but the preference is not different between the two gender. And, although being aware of gender-marking styles may not lead to effective teaching, science teachers, in order to be more effective, still need to recognize these differences as a whole and subsequently need to broaden their range of teaching styles accordingly.

\section{REFERENCE}

[1] Coffield F., D. Moseley, E. Hall, and K. Ecclestone. (2004) Learning styles and pedagogy in post-16 learning: a systematic and critical review. London: Learning and Skills Research Centre

[2] Hawk T.F. and Amit J.S. 2007. Using Learning Style Instruments to Enhance Student Learning. Decision Sciences Journal of Innovative Education. 5(1): 1-19

[3] Fleming, N.D. and Mills, C. (1992) Not Another Inventory, Rather a Catalyst for Reflection. To Improve the Academy. 11: 137-155

[4] Valerdi, Ricardo \& Jain, Rashmi \& Ferris, T.L.J. \&Kasser, Joseph. (2009). An Exploration of Matching Teaching to the Learning Styles of Systems Engineering Graduate Students. INCOSE International Symposium.

[5] Dobson, John. (2010). A comparison between learning style preferences and sex, status, and course performance. Advances in physiology education. 34: 197-204.

[6] James S, D'Amore A, Thomas T. Learning preferences of first year nursing and midwifery students: utilising VARK. (2011). Nurse Educ Today. 31(4):417-23.

[7] Peyman, Hadi\&Sadeghifar, Jamil \&Khajavikhan, Javaher\&Yasemi, Masood \&Yasemi, Mohammad \&Yaghoubi, Monireh\&nAHAl, MoniReH\& Karim, Hemati. (2014). Using VARK Approach for Assessing Preferred Learning Styles of First Year Medical Sciences Students: A Survey from Iran. Journal of Clinical and Diagnostic Research. 8: 1-4.

[8] Slater JA, Lujan HL, DiCarlo SE. Does gender influence learning style preferences of first-year medical students? (2007). AdvPhysiol Educ. 31(4):336-42.

[9] Breckler J, Teoh CS and Role K. (2011) Academic performance and learning style self-predictions by second language students in an introductory biology course. Journal of the Scholarship of Teaching and Learning. 11(4): 26-43

[10] Wehrwein, E., Lujan, H., \&DiCarlo, S. (2007). Gender differences in learning style preferences among undergraduate physiology student. Journal of Advances in Physiology Education. 31: 153-175

[11] Nurlia, Nurlia\&Hala, Yusminah\&Muchtar, Rachmawaty\&Jumadi, Oslan\&Taiyeb, Mushawwir. (2017). Hubungan Antara Gaya Belajar, KemandirianBelajar, danMinatBelajardenganHasilBelajarBiologiSiswa. JurnalPendidikanBiologi. 6(2):321-328

[12] Suryani, E. (2017). HubunganKreativitasdan Gaya BelajarterhadapHasilBelajarKognitifBiologi SMA. BIOEDUKASI. 8(2): 150-162

[13] Willingham, D.T., E. M. Hughes, and D. G. Dobolyi. (2015). The Scientific Status of Learning Styles Theories. Teaching of Psychology. 42(3): 266-271.

[14] Sternberg, R. J. and E. L. Grigorenko. (1997). Are cognitive styles still in style? American Psychologist. 52(7): 700-12.

[15] Yi, W. C., Hui, H. W., \& Jasmine, S. (2011). Relationship between learning styles and Content Based Academic Achievement among Tertiary Level Students. In The Enhancing Learning: Teaching and Learning Conference.

[16] Yemane Y, Ambaye E, Alehegn A, Sahile E, Dimtsu B, et al. (2017) Assessment of Gender Difference on Learning Styles Preferences among Regular Undergraduate Students of Mekelle University Collage of Health Science. J. Stem Cell Biol. Transplant. 1(2): 14.

[17] Güneş, M. H .Learning Styles of the Students of Biology Department and Prospective Biology Teachers in Turkey and Their Relationship with Some Demographic Variables.(2018) Universal Journal of Educational Research. 6(3): 366 - 377.

[18] Suprihadi, Suprihadi and ROKHAYANI, Atik. (2017) Relationship between Gender, Subject Preference and Learning Styles. . Relationship between Gender, Subject Preference and Learning Styles. Celt: A Journal of Culture, English Language Teaching \& Literature. 16(2): 242-270,

[19] Braakhuis, A., T. Williams., E. Fusco., S. Hueglin., A. Popple. (2015). A Comparison between Learning Style Preferences, Gender,Sport and Achievement in Elite Team Sport Athletes. Sports2015(3): 325-334 
[20] Kashefian-Naeeini, S., Maarof, N., \&Salehi, H. (2011, October). Malaysian ESL learners' use of language learning strategies. In International Conference on Humanities, Society and Culture. 20: 340-344).

[21] Ismail, M., Shah, A., Ismail, Y., Esa, Z., \& Muhamad, A. J. (2013). Language learning strategies of English for specific purposes students at a public university in Malaysia. English Language Teaching.6 (1): 153-161.

[22] Shuaib and Azizan. (2015) Learning Style Preferences Among Male and Female ESL Students in Universiti-Sains Malaysia. The Journal of Educators Online. 13 (2): 103-141

[23] Paechter, C. (2004). The gendered curriculum. In Claire, H. (Ed.), Gender in education 3-19: A fresh approach. Retrieved from http://www.atlcymru.org.uk/Images/Gender\%20in\%20education\%203-19.pdf

[24] Rosseni Din, M. Kamarulzaman, F., Norman, H., Shah, P. M., Karim, A. A., Johar, N. A. \&Verawati, I. (2012). Detecting gender biasness via gender differential item functioning analysis on integrated meaningful hybrid elearning instrument. WSEAS Transaction on Advances in Engineering Education. 3(9): 63-71.

[25] Tulbure C (2012) Investigating the relationships between teaching strategies and learning styles in higher education. ActaDidacticaNapocensia 5(1): 65-74

[26] Alghasham, A. A. (2012). Effect of students' learning styles on classroom performance in problem-based learning. Medical Teacher. 34(1): 14-19

[27] Alkooheji Lamya and Al-Hattami (2018). Learning Styles Preference Among College Students. International Education Studies. 11 (10):50-63

\section{AUTHORS' BIOGRAPHY}

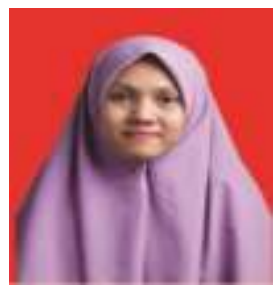

Hafizhah Dini Nasution, S.Pd, is a biology education postgraduate student at Postgraduate Program of UniversitasNegeri Medan (State University of Medan), Medan, North Sumatera, Post code 20221, Indonesia. She earned her graduate degree from Biology Bilingual Education Program of UniversitasNegeri Medan, Indonesia nd her master degree at Postgraduate Biology Education Program of UniversitasNegeri Medan, Indonesia.

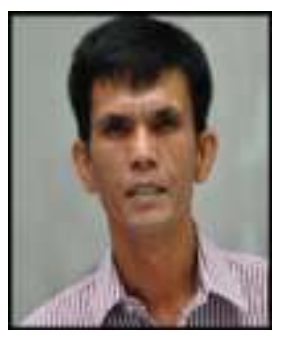

Prof. Dr. Herbert Sipahutar, M.S., M.Sc, is a professor in cell and molecular biology of the Biology Education Study at Graduate and Postgraduate Programe of UniversitasNegeri Medan (Medan State University), Medan, North Sumatera, Post code 20221, Indonesia. He earned his graduate degree at Biology Education Program of IKIP Medan, Indonesia; his master degree at Biology Program of InstitutTeknologi Bandung, Indonesia and also at Zoology Program of University of Tasmania, Australia. His doctorate degree earned at Cell and Molecular Biology Program of Universite' de Caen, France.

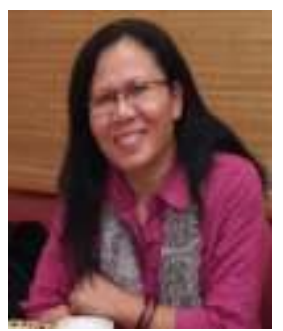

Dr. Tumiur Gulton S.P., M.P, is a Lecturer at Graduate and Postgraduate Programe of Universitas Negeri Medan (Medan State University), Medan, North Sumatera, Post code 20221, Indonesia. She earned her graduate degree at Agriculture Program of Universitas Pattimura, Ambon, Indonesia; her master degree earned at Agriculture Program of Universitas Sumatera Utara and her doctorate degree earned at Plant Breeding Program of Universitas Gajah Mada, Yogjakarta, Indonesia.

Citation: Herbert Sipahutar, et.al. "Gender Differences in Learning Style Preferences among Eleventh Grade Science Major High School Students". International Journal of Humanities Social Sciences and Education (IJHSSE), vol. 6, no.11, 2019, pp. 51-56. doi: http://dx.doi.org/10.20431/2349-0381.0611008.

Copyright: (c) 2019 Authors. This is an open-access article distributed under the terms of the Creative Commons Attribution License, which permits unrestricted use, distribution, and reproduction in any medium, provided the original author and source are credited. 